\title{
НОРМАТИВНО-ПРАВОВЫЕ АСПЕКТЫ РЕГУЛИРОВАНИЯ ТУРИСТСКО-ЭКСКУРСИОННОЙ ДЕЯТЕЛЬНОСТИ В РЕСПУБЛИКЕ БУРЯТИЯ (КОНЕЦ ХХ - НАЧАЛО ХХІ)
}

В данной статье рассматриваются основные законы в области туристско-экскурсионной деятельности, принятые в Республике Бурятия. Анализируются программы развития туризма, приведены их отличительные особенности.

Ключевые слова: туризм, закон, нормативно-правовой акт, программа развития, Бурятия.

U.S. NIKOLOVA

\section{NORMATIVE LEGAL ASPECTS OF REGULATION OF TOURIST AND EXCURSIVE ACTIVITIES IN THE REPUBLIC OF BURYATIA (THE END OF THE 20th CENTURIES - THE BEGINNING OF THE 21st CENTURIES)}

This article considers the basic laws in the field of tourist and excursion activities adopted in the Republic of Buryatia. The programs of tourism development are analyzed, their distinctive features are provided.

Keywords: tourism, law, normative legal act, development program Buryatia.

В современном мире туризм становится не только потребностью, но и нормой жизни большинства людей. Он представляет собой одну из постоянно развивающихся отраслей мирового хозяйства, играет важную роль в обеспечении социально-экономического развития государства, способствует высокому уровню занятости населения, а также содействует фрормированию конкурентоспособного национального туристского комплекса. Из опыта многих стран следует, что развитие туризма, в первую очередь, зависит от того, как и в каком объеме государство оказывает поддержку этой сфере [3, с. 87].

С каждым годом растет необходимость правового регулирования туристской деятельности. Это связано и с такой особенностью туризма, выражающейся в том числе в складывающихся отношениях международного характера, в которые вступают как лица, участвующие в организации отдыха и путешествий, так и потребители услуг туристской индустрии. 
Немаловажную роль играет и экономическая сторона этой деятельности. Сегодня справедливо можно отметить, что процесс формирования современного российского законодательства в сфере туристской деятельности по существу только начинается, поскольку Россия стала приводить свое национальное законодательство в соответствие с общепринятыми международно-правовыми нормами только с середины 90-х гг. XX в. [3, с. 88].

Первые научные разработки, посвященные различным аспектам правового регулирования туристской деятельности в России, появились в конце 90-х гг. XX в. Вопросы истории развития туризма, в целом и его правового регулирования в разные годы были предметом исследования многих ученых, среди которых: В.В. Дворниченко, Ю.Н. Соколов, В.Е. Иванов, А.П. Иванов, П.А. Петухов, К.Г. Борисов, Г.И. Тархова, Л.В. Щенникова, Н.С. Барчукова, К.А. Комаров, С.С. Алексеев, В.И. Андреев, Л.О. Красавчикова, В.М. Лебедев, Л.Б. Оссовская и др. [16, с. 20-21]. Особо следует отметить диссертационное исследование Е.Л. Писаревского «Правовое регулирование туристской деятельности», в котором комплексно рассмотрена история туристского права [15].

Однако, несмотря на весьма широкий круг ученых и практиков, исследующих историю нормативно-правового регулирования туризма, обращает на себя внимание фракт недостаточного комплексного изучения и освещения особенностей регулирования туризма на региональном уровне. В полной мере это относится и к Республике Бурятия. В связи с этим, в нашей статье предпринята попытка рассмотреть законы и нормативно-правовые акты принятые на территории Республики Бурятия в конце XX - начале XXI в.

В настоящее время основным нормативно-правовым документом в области туристско-экскурсионной деятельности является Закон Республики Бурятия «О туризме» от 21 ноября 1995 г., принятый Народным Хуралом Республики Бурятия.

Принятие этого закона было обусловлено тем, что в это время Бурятия занимала одно из последних мест на российском рынке туризма и практически не была представлена на международном рынке. Государственные инвестиции в развитие туризма не производились до 1996 г. [12].

Закон Республики Бурятия «О туризме» установил экономические и правовые гарантии туризма и туристской деятельности на территории Республики Бурятия, а также регулировал отношения в сфрере туризма, туристской деятельности, рационального использования туристских ресурсов. Туризм стал рассматриваться как одно из приоритетных направлений устойчивого развития экономики Бурятии и как один из гарантов безопасности озера Байкал, являющимся участком мирового наследия. Также были введены основные понятия, правовые основы туризма и туристской деятельности в республике, права и обязанности туриста [12]. Закон «О туризме» является действующим и основным в сфере туризма 
в Бурятии. С 1995 г. и до настоящего времени в закон шесть раз вносились изменения.

Среди других законов, влияющих на развитие сферы туризма можно выделить Закон Республики Бурятия «О лечебно-оздоровительных местностях, курортах в Республике Бурятия» от 16 сентября 1997 г. № 559-І. Принятие закона было обусловлено тем, что Республика Бурятия обладает разнообразными минеральными и термальными источниками, запасами лечебных грязей. Закон регулировал отношения в области функционирования, развития и охраны курортов, лечебно-оздоровительных местностей и природных лечебных ресурсов в Республике Бурятия. Были обозначены особенности использования природных ресурсов, санитарная охрана лечебно-оздоровительных местностей, правовое и экономическое регулирование в сфере курортного дела. За Правительством РБ закреплялось право признания территории лечебно-оздоровительной местностью, курортом федерального или местного значения, а также принятие нормативно-правовых актов и концепций развития лечебно-оздоровительных местностей, курортов [8].

Среди мероприятий, направленных на совершенствование нормативно-правового регулирования в сфере туризма, территориальную организацию туризма, был разработан Закон Республики Бурятия «О зонах экономического благоприятствования в Республике Бурятия» от 14 марта 2007 г. № 2073-ІІІ. В соответствии с законом было создано 12 зон экономического благоприятствования туристско-рекреационного типа в Иволгинском, Кяхтинском, Заиграевском, Тункинском, Северо-Байкальском, Кабанском, Прибайкальском, Селенгинском районах, г. Улан-Удэ, г. Северобайкальск [6].

Вопросы развития туризма и туристской деятельности на территории Бурятии контролируются и координируются исполнительным органом государственной власти Республики Бурятия [12]. С 1998 по 2005 г. таким органом являлся Государственный комитет Республики Бурятия по делам молодежи, туризму, физической культуре и спорту. Основными задачами Госкомитета в области туризма являлись: содействие формированию развернутой инфраструктуры и развитию материально-технической базы туризма и санаторно-курортной сферы, осуществление государственной политики и создание целостной нормативно-правовой системы в сорере санаторно-курортного лечения и отдыха с повышением доступности санаторно-курортного лечения для большинства населения и его эффективности, подготовка предложений по привлечению иностранных инвестиций для развития туризма, координация международных туристических связей Республики Бурятия и содействие их расширению, а также контроль за реализацией государственной молодежной политики, государственной политики в области туризма и санаторно-курортной сферы, физической культуры и спорта [7]. 
В целях совершенствования государственного управления в Республике Бурятия и оптимизации структуры исполнительных органов государственной власти Президентом РБ был издан указ «О республиканском агентстве по туризму» от 23 августа 2005 г. № 420. Агентству были переданы функции Министерства экономического развития и внешних связей Республики Бурятии по оказанию государственных услуг и правоприменительные фрункции в сфрере туризма. Согласно Постановлению «Об утверждении Положения о Республиканском агентстве по туризму» от 21 октября 2005 г. № 339 были закреплены задачи и полномочия агентства по туризму, организация деятельности, а также утверждена структура управления. Агентство должно было выполнять две основные задачи. Это оказание государственных услуг и осуществление правоприменительных функций [11].

В 2015 г. агентство было реорганизовано: с 1 октября оно становится Комитетом по туризму Министерства экономики республики. В 2017 г. функции Министерства экономики Республики Бурятия по реализации государственной политики и нормативно-правовому регулированию в области туризма, а также по оказанию государственных услуг и правоприменительные функции в сфере туризма перешли к созданному Министерству туризма Республики Бурятия. Министерство было утверждено Постановлением Правительства «Об утверждении Положения о Министерстве туризма Республики Бурятия» от 25 декабря 2017 г. № 609. К основным задачам Министерства относятся оказание государственных услуг организациям и населению в сфере туризма, планирование развития сфреры туризма в Республике Бурятия и формирование республиканской системы туристского маркетинга с целью создания конкурентоспособного туристско-рекреационного комплекса. В структуре органа Комитет стратегического управления развитием туризма и Комитет продвижения туристского продукта и поддержки субъектов туристской индустрии [13].

Кроме законов, нормативно-правовая база туризма в Российской федерации в том числе и в Республике Бурятия складывается из программ развития туризма. На необходимость развития ссреры туризма программными методами указывала практика стран с развитой индустрией туризма. Такие методы позволяли оптимизировать осуществление государственной политики в этой области и быстрее достигать ожидаемых экономических эфрфектов [10].

В целях определения ориентиров развития сферы туризма и выработки его основных направлений Постановлением Правительства Республики Бурятия от 5 апреля 1996 г. № 125 была утверждена первая республиканская целевая программа «Развитие туризма в Республике Бурятия на 1997-2006 гг.».

Программа была направлена на создание правовой организационной и экономической среды для формирования современной туристской индустрии в Республике Бурятия, содействия развитию материальной 
базы туризма. Программа была призвана стимулировать процесс становления в ссрере туризма современных рыночных отношений и адекватных им механизмов государственного регулирования. Документ был подготовлен Государственным комитетом РБ по делам молодежи, туризму, физической культуре и спорту при участии Государственного комитета РФ по фризической культуре и туризму, республиканских министерств и ведомств, Байкальского института рационального природопользования, Байкальской региональной ассоциации туризма [10].

Программа согласовалась в основных своих положениях с Федеральной целевой программой «Развитие туризма в Российской Федерации» (1995). Основные задачами Программы являлись: содействие в создании современного отечественного рынка туризма на основе развития конкуренции, участие в формировании современной нормативно-правовой базы развития туризма на основе нормативно-правовых актов Российской Федерации и Республики Бурятия; создание условий для приоритетного развития внутреннего и въездного туризма; программное обеспечение отдельных перспективных и социально значимых видов туризма; интеграция Бурятии в систему отечественного и мирового туристского рынка и развитие международного сотрудничества в области туризма.

Реализация программы состояла из двух этапов. Первый этап должен быть реализован в 1997-1999 гг. и включал в себя разработку и реализацию системы мероприятий, направленных на формирование нормативно-правовой базы развития туризма, механизмов государственного регулирования, рекламно-информационного, кадрового и научного обеспечения. На этом этапе ожидалась стабилизация и начало постепенного роста внутреннего и въездного туризма. Второй этап с 2000 по 2005 г. предполагал завершение работ по созданию современной системы подготовки кадров, активизацию инвестиционной деятельности в сфере туризма, развертывание широкомасштабной рекламной кампании по продвижению туристского продукта Бурятии на мировом рынке. На этом этапе предполагался дальнейший рост туристских потоков [10].

Выполнение намеченных Программой мероприятий должно было привести к значительному укреплению материальной базы туризма, росту комфортабельности средств размещения, расширению географии и многообразию туристских маршрутов и соответственно, обеспечить значительное расширение притока в республику иностранных туристов.

В начале 2000-х гг. туристская сфера в Бурятии продолжает развиваться программными методами. В 2006 г. Правительство утвердило Постановление «О Республиканской целевой программе «Развитие туризма в Республике Бурятия на 2007-2010 гг.» от 23 октября 2006 г. № 340. Отличительной особенностью данной программы стала реализация решения Правительства Российской Федерации о создании особых экономических зон на территории Республики Бурятия. 
Основной целью Программы являлось создание условий для ускорения темпов развития туристско-рекреационного комплекса Республики Бурятия и его эффрективного продвижения на рынке туризма. К задачами Программы было формирование системы взаимодействия, координации и управления развитием кластера «Туризм», обеспечение обязательств Республики Бурятия по созданию особой экономической зоны туристско-рекреационного типа, развитие материальной базы и инфраструктуры туризма на условиях государственно-частного партнерства, содействие повышению качества туристского продукта и обеспечению безопасности туристов, приведение в соответствие с современными мировыми стандартами материальных и организационных условий объектов туризма, развитие и повышение конкурентоспособности самого туристического кластера, стимулирование создания и поддержка деятельности профессиональных объединений, расширение известности туристического кластера республики на профессиональных рынках на основе развития республиканской системы туристского маркетинга, расширение международного и межрегионального сотрудничества на основе разработки трансграничных туристических маршрутов [9].

В рамках выполнения задач Программы Постановлением Правительства РФ «О создании на территории муниципального образования “Прибайкальский район" Республики Бурятия особой экономической зоны туристско-рекреационного типа» от 3 феевраля 2007 г. № 68 была создана ОЭЗ ТРТ «Байкальская гавань». Протяженность береговой линии озера вдоль территории ОЭЗ составляет порядка 60 км. Расстояние от г. Улан-Удэ - 110 км. Основная цель создания ОЭЗ ТРТ «Байкальская гавань» было формирование центра международного туризма на востоке России, повышение конкурентоспособности туристского и санаторно-курортного продукта с использованием уникального природного объекта - озера Байкал. Особая экономическая зона специализируется на горнолыжном туризме, СПА, лечении методами восточной медицины, круизах по Байкалу и семейному отдыху. «Байкальская гавань» включает в себя 5 участков: «Пески», «Турка», «Горячинск», «Бухта Безымянная», «Гора Бычья». 1 июня 2017 г. управление ОЭЗ было передано на региональный уровень [14].

В 2010 г. была утверждена новая Республиканская целевая программа «Развитие внутреннего и въездного туризма в РБ на 2011-2016 гг.» Постановлением РБ от 2 ноября 2010 г. № 462. Основной целью Программы являлось фрормирование и повышение конкурентоспособности кластера «Туризм», удовлетворяющего потребности российских и иностранных граждан в качественных туристских услугах.

Реализация Программы должна была быть осуществлена в три этапа. На первом (подготовительном) этапе (2011) планировалось создание организационно-экономических предпосылок и улучшение условий для 
предпринимательской и инвестиционной деятельности в сфере туризма. На этапе внедрения (2012-2013) предусматривалось проведение работ по созданию наиболее важных и значимых объектов современных туристских комплексов на подготовленных инвестиционных площадках, в зонах экономического благоприятствования. И на заключительном, третьем этапе (2014-2016) планировалось создание обширной региональной сети курортных и туристских объектов, отвечающих мировым стандартам и способных значительно повысить конкурентоспособность рынка туристских услуг [15].

Кроме республиканских программ развития туризма на территории Бурятии проводятся мероприятия в рамках федеральных целевых программ. В соответствии с федеральной целевой программой принятой Постановлением Правительства Российской Федерации «О Федеральной Целевой программе «Развитие внутреннего и въездного туризма в Российской Федерации (2011-2018 гг.)» от 2 августа 2011 г. № 644 на территории Республики Бурятия с 2012 г. осуществляется реализация мероприятий по созданию туристско-рекреационного кластера «Подлеморье» (Кабанский район), автотуристских кластеров «Кяхта» (Кяхтинский район), «Байкальский» (Иволгинский район), «Тункинская долина» (Тункинский район).

Объем средств, направленных на реализацию программных мероприятий по созданию указанных туристских кластеров, по состоянию на 1 января 2018 г. составил более 5 млрд р., в том числе из средств федерального бюджета - 1,5 млрд р., республиканского бюджета 0,35 млрд р., внебюджетных источников - 3,46 млрд р.

Концепцией Федеральной целевой программы «Развитие внутреннего и въездного туризма в Российской Федерации (2019-2025 гг.)» выделен перспективный туристский укрупненный инвестиционный проект «Байкал», основой которого является уникальная экосистема озера Байкал и Байкальской природной территории, обладающий высоким потенциалом для развития экологического туризма [17].

Согласно Концепции, рекреационное использование озера Байкал с учетом природоохранных требований обусловливает необходимость развития инфраструктуры организованного туризма и отдыха на побережье озера, а также создания альтернативных мест притяжения туристского интереса.

С учетом положений Концепции для включения в проект федеральной целевой программы «Развитие внутреннего и въездного туризма в Российской Федерации (2019-2025 гг.)» подготовлены предложения по туристскому кластеру «На Великом Чайном пути» (Кяхтинский, Селенгинский, Тарбагатайский, Кабанский районы, город Улан-Удэ) [17].

На сегодняшний день в регионе действует Государственная программа Республики Бурятия «Развитие внутреннего и въездного туризма в Республике Бурятия», принятая Постановлением Правительства 
Республики Бурятия от 25 сентября 2018 г. № 524 г. Улан-Удэ. Сроки реализации Программы 2019-2021 гг.

Целью Программы является создание конкурентоспособной туристской индустрии Республики Бурятия, способной удовлетворить потребности как российских, так и иностранных туристов. Основные задачи: комплексное развитие инфраструктуры туризма с учетом минимизации экологического ущерба, повышение качества и конкурентоспособности туристского продукта Республики Бурятия, позиционирование Республики Бурятия как международного центра туризма на востоке России, совершенствование системы управления в сфере туризма [5].

Также в настоящее время Министерством туризма разрабатывается «Стратегия развития внутреннего и въездного туризма в Республике Бурятия на период до 2030 г.» и «Правила организации туризма и отдыха в центральной экологической зоне Байкальской природной территории» [2, с. 13-14].

Таким образом, развитие нормативно-правовой базы в области туристско-экскурсионной деятельности началось только в 1995 г. До этого, в республике действовали фредеральные законы, подзаконные акты, положения и указы. В основном сфера туризма в Бурятии развивалась и развивается программными методами. Об этом говорит принятие четырех программ развития туризма (1997-2005 гг., 2007-2010 гг., 20112016 гг., 2019-2021 гг.). Основным же законом, принятым в 1995 г. и действующим на сегодняшний день, является Закон «О туризме».

Законодательная база, созданная в Бурятии за последние 23 года, регулирует практически все сферы туристской деятельности и смежные с ней. Изменения в нормативно-правовой базе происходят в соответствии со внешней средой, в ответ на политические, экономические и социальные фракторы. В связи с этим, необходим постоянный мониторинг действующих нормативных актов и редактирование их для поддержания стабильного развития туристской отрасли.

\section{Список использованной литературы и источников}

1. Захарова Е. П. Туристская деятельность в Российской Федерации: источники правового регулирования / Е. П. Захарова // Вестник Саратовской государственной юридической академии. — 2013. — № 6. - С. 87-91.

2. Материалы к заседанию круглого стола «О ходе реализации закона Республики Бурятия «О туризме»» Народный Хурал Республики Бурятия, Комитет по экономической политике, использованию природных ресурсов и охране окружающей среды, г. Улан-Удэ, 26 марта 2018. - 30 с.

3. Об утверждении Республиканской целевой программы «Развитие внутреннего и въездного туризма на 2011-2016 гг. : постановление Правительства РБ от 2 ноября 2010 г. № 462 [Электронный ресурс] // Электронный фонд правовой и нормативно-технической документации. - Режим доступа : http://docs.cntd. $\mathrm{ru} /$ document/473810798 
4. Об утверждении Положения о Республиканском агентстве по туризму : постановление Правительства Республики Бурятия от 21 октября 2005 г. № 339 [Электронный ресурс] // Электронный фонд правовой и нормативно-технической документации. - Режим доступа : docs.cntd.ru/document/ 816001179

5. Об утверждении Государственной программы Республики Бурятия «Развитие внутреннего и въездного туризма в Республике Бурятия» : постановление Правительства Республики Бурятия от 25 сентября 2018 г. № 524 [Электронный ресурс] // Электронный фонд правовой и нормативно-технической документации. - Режим доступа : http://docs.cntd.ru/document/550205479

6. О зонах экономического благоприятствования в Республике Бурятия : закон РБ принятый Народным Хуралом РБ от 14 марта 2007 г. № 2073-ІІІ (ред. от 13.03.2017) [Электронный ресурс] // КонсультантПлюс. - Режим доступа : http:// www.consultant.ru/regbase/cgi/online

7. О Государственном комитете Республики Бурятия по делам молодежи, туризму, физической культуре и спорту : постановление Правительства РБ от 16 декабря 1998 г. № 419 [Электронный ресурс] // Электронный фонд правовой и нормативно-технической документации. - Режим доступа : http://docs.cntd.ru/ document/473810218

8. О лечебно-оздоровительных местностях, курортах в Республике Бурятия : закон РБ от 16 сентября 1997 г. № 559-I 340 [Электронный ресурс] // Электронный фонд правовой и нормативно-технической документации. - Режим доступа : URL http://docs.cntd.ru/document/802039027

9. О Республиканской целевой программе «Развитие туризма в Республике Бурятия на 2007-2010 годы : постановление Правительства РБ от 23 октября 2006 г. № 340 [Электронный ресурс] // Электронный фонд правовой и нормативно-технической документации. - Режим доступа : http://docs.cntd.ru/document/802078960

10. О республиканской целевой программе «Развитие туризма в Республике Бурятия на 1997-2006 гг.» : постановление Правительства РБ от 15 апреля 1996 г. № 125 [Электронный ресурс] // Электронный фонд правовой и нормативно-технической документации. - Режим доступа : http://docs.cntd.ru/document/473801312

11. О Республиканском агентстве по туризму : указ Президента РБ от 23 августа 2005 г. № 420 [Электронный ресурс] // Электронный фонд правовой и нормативно-технической документации. - Режим доступа : http://docs.cntd.ru/ document/816000701

12. О туризме : закон Республики Бурятия от 21 ноября 1995 г. № 210-І [Электронный ресурс] // Электронный фонд правовой и нормативно-технической документации. - Режим доступа : http://docs.cntd.ru/document/802039023

13. Офицциальный сайт Министерства туризма РБ [Электронный ресурс]. Режим доступа : http://egov-buryatia.ru/minturizm

14. ОЭЗ ТРТ «Байкальская гавань» [Электронный ресурс] // Инвестиционный портал Республики Бурятия. - Режим доступа : http://invest-buryatia.ru/index/ investiczionnyie-predlozheniya/turistsko-rekreaczionnyij-kompleks

15. Писаревский Е. Л. Правовое регулирование туристской деятельности : автореф. канд. ... юрид. наук [Электронный ресурс] / Е. Л. Писаревский // Электронная библиотека диссертаций. - Режим доступа: http://www.dslib.net/civilpravo/pravovoe-regulirovanie-turistskoj-dejatelnosti.html

16. Правовое обеспечение туризма : учебник / под ред. Е. Л. Писаревского. - М. : Федеральное агентство по туризму, 2014. - 336 с. 
17. Федеральная целевая программа «Развитие внутреннего и въездного туризма в Российской Федерации (2019-2025 гг.)» : распоряжение от 5 мая 2018 г. № 872-р [Электронный ресурс] // Федеральное агентство по туризму. - Режим доступа : http:// https://www.russiatourism.ru

\section{Информация об авторе}

Николова Юлия Станиславовна - преподаватель, кафедра туризма, сервиса и физического воспитания, Восточно-Сибирский государственный институт культуры, 670031, г. Улан-Удэ, ул. Терешковой, 1; e-mail: 12julia1295@mail.ru

\section{Author}

Ulia S. Nikolova - Lecturer, Department of Tourism, Service and Physical Education, East-Siberian State Institute of Culture, 1 Tereshkova St., 670031, Ulan-Ude, Russia; e-mail: 12julia1295@mail.ru 